Original Research Paper

\title{
Effect of the Strategic Supplementation for Producing Embryos of Native Hartón del Valle Heifers
}

\author{
1,2 Adrian Rolando Riascos-Vallejos, ${ }^{4}$ Julio Jesus Reyes-González, \\ ${ }^{3}$ Yolaine Medina-Mesa and ${ }^{2}$ Juan Pablo Narvaez-Herrera \\ ${ }^{1}$ Department of Ruminants, Institute of Animal Science, San José de las Lajas, Mayabeque, La Habana, Cuba \\ ${ }^{2}$ Arapaima Fishery and Agroforestry Center, National Learning Service (SENA), \\ Regional Putumayo, Puerto Asís, Putumayo, Colombia \\ ${ }^{3}$ Department of Applies Biostatistics, Institute of Animal Science, San José de las Lajas, Mayabeque, La Habana, Cuba \\ ${ }^{4}$ Institute of Research on Pastures and Forage, La Habana, Cuba
}

Article history

Received: 14-08-2020

Revised: 12-02-2021

Accepted: 04-03-2021

Corresponding Author: Adrian Rolando Riascos-Vallejos Arapaima Fishery and Agroforestry Center, National Learning Service (SENA), Regional Putumayo, Puerto Asís, Putumayo, Colombia Email: rolando.riascos@gmail.com

\begin{abstract}
Nutritional imbalances have been confirmed in other breeds, related to energy, proteins and minerals and this affects embryonic development, production of quality. In this regard, the objective of this research was to evaluate the effect of strategic supplementation for the production of embryos in native Hartón del Valle heifers. For that purpose, 18 pure heifers were used, fed with a diet containing $0.708 \mathrm{~kg}$ of crude protein and $73.58 \mathrm{~kg}$ of ME Mjul. The economic evaluation was carried out using the partial budgeting technique. Treatments consisted of T1: Without supplementation, T2: Supplementation, 42 days before protocol, T3: 42 days of supplementation, 26 days before and 16 days during protocol. Variables evaluated were number of structures, transferable embryos, number of NonTransferable Embryos (NTE), number of corpora lutea, follicles and embryonic quality. Non parametric analysis of variance was performed, according to a completely randomized design and comparison of proportions (chi-square). When analyzing the proportion of NTE Vs. the total, it was lower $(p<0.05)$ in supplemented treatments, regardless of the period in which supplementation was carried out. Supplementation, in both phases of the protocol, increased the proportions of early morulae and blastocysts $(p<0.05)$. In the economic analysis, profits increased by 2.05 and 1.53 times in favor of the supplementation. Supplementation to Hartón del Valle heifers, before and during superovulation, favored the biological response of collected structures, number of follicles and corpora lutea. Similarly, the proportion of transferable embryos, early morulae and quality one blast cells increased, in addition to achieving a higher cost/benefit relationship.
\end{abstract}

Keywords: Piptocoma discolor, Putumayo, Blastocyst, Superovulation

\section{Introduction}

In the technological development of cattle rearing field, there is a search for optimizing the conservation of genetic resources (Prenteci and Anzar, 2011). This is also applied to assisted reproduction. In this regard, embryo production is one of the methods for boosting livestock production in the world mundo (Borge et al., 2019). In native Hartón del Valle cattle, this method is a tool for germplasm conservation, used in Colombia, with institutions such as the Colombian Corporation for Agricultural Research (AGROSAVIA) and private farms (Martínez, 2019). Native breeds are considered to be in danger of extinction. However, variability of embryonic response depends on different factors such as environmental, technical, genetic and nutritional management. The latter takes relevance due to the effect of nutrients on embryonic development (Buerkle, 2007).

In some cases, nutritional balance of donors is inappropriate due to specific conditions of soils (Staal et al., 2020). In the Colombian Amazon, the problem increases because soil is unsuitable for livestock activity, which makes soil-plant-animal relation to be limited for some nutrients nutrientes (Suárez et al., 2018; Mathios Flores et al., 2019; Staal et al., 2020), especially when it is necessary to fulfill the minimum requirements 
of bovines to obtain favorable results, in terms of oocyte quantity and embryo quality (Calderón et al., 2017).

This response is given by the development of antral follicles, mediated by the Follicle-Stimulating Hormone (FSH) action, as one of the important factors that affect embryo production in cattle (Ibtisham et al., 2018). Antral follicle development is correlated with multiple ovulation. A nutritional flushing could increase maturation of primary follicles, due to the increase of Insulin Growth Factor (IGF1) insulina (Larson and White, 2016). These factors increase the sensitivity of granulosa cells and stimulate receptors for Luteinizing Hormone (LH). However, a high amount of insulin in blood compromises embryo viability and quality (Rossetto et al., 2016).

In this context, the Amazonian piedmont includes a wide variety of species, suitable for animal feeding animal (Moniruzzaman and Miyano, 2010; Sotelo et al., 2017, Riascos-Vallejos et al., 2020a). This fact allows to state that there are forage resources of high quality in the Amazonian area, with potential for animal feeding. Supplements based on these species, with proper contents of protein, energy, minerals and degradability, compensate animal requirements because livestock production systems, in this region, base their feeding on native grasses (Riascos-Vallejos et al., 2020b; Cardona-Iglesias et al., 2016).

A diet that meets all nutritional requirements, in different periods, could have a positive effect on embryo production. Therefore, the objective of this research was to evaluate the effect of a strategic supplementation for embryo production of Hartón del Valle heifers.

\section{Materials and Methods}

\section{Location}

This research was conducted in Villa Lucero farm, at $0^{\circ} 35^{\prime} 25.6^{\prime \prime} \mathrm{N} 76^{\circ} 32^{\prime} 05.3 \mathrm{\prime W}$, in Putumayo department, Republic of Colombia, at 256 m.a.s.l. There is $25.3^{\circ} \mathrm{C}$ as mean temperature, $85 \%$ of relative humidity and 3,355 $\mathrm{mm}$ of average annual rainfall (IDEAM, 2017), belonging to a life area of tropical humid forest (Holdridge, 1987; Landínez-Torres, 2017).

\section{Animals and Reproductive Diagnosis}

For this study, 18 Hartón del Valle heifers were selected, with $34 \pm 2$ months of age and body weight of $340 \pm 20 \mathrm{~kg}$, were selected. Prior to the beginning of experimentation, these animals underwent a general physical examination, including the evaluation of morphology and integrity of their reproductive tract, according to Schneider methodology (Schneider et al., 2012). A portable ultrasound equipment (Econ Control Medical Ref. IMAGO), with a 7.5 MHz linear transducer, was used, to confirm the absence of pregnancy, assess ovarian condition and verify the absence of cysts, adhesions and other pathologies. Furthermore, the absence of fibrosis and malformations was confirmed by passing through the cervix with a catheter.

\section{Feeding}

Heifers were fed a diet containing $0.690 \mathrm{~kg}$ of crude protein and $79.53 \mathrm{~kg}$ of Metabolizable Energy (ME Mjul $\left.\mathrm{kg} \mathrm{DM}^{-1}\right)$. They received a supplement containing Piptocoma discolor (28, 29), corn, soybean cake, corn bran, molasses, palm oil and mineral premix (Table 1).

A supplement of $2 \mathrm{~kg}$ was offered per day in the period of 7:00 bm-9:00 am, then they went to grazing Brachiaria decumbens was used as forage source (Ruíz and Menchaca, 1990). Food balance calculation was performed according to nutritional requirements (NRC, 2001). It was carried out with CALRAC® computer program (version 1.0).

Proximal chemical analyzes (Table 1) were calculated, according to procedures and recommendations established by (AOAC, 2016), as follows: Humidity content (Method 930.04), crude protein by Kjeldahl method $\left(\mathrm{N}^{*} 6.25\right)$ (method 955.04), ashes (calcination at 6,000) (method 930.05), ether extract (method 962.09) and crude fiber (method 920.39). Gross Energy (GE) was determined with a calorimetric pump. Digestibility of Dry Matter (DM) was reached according to (Ariza-Nieto et al., 2018) methodology and in situ ruminal degradability by (Chen et al., 1990; Mehrez and Orskov, 1997).

\section{Superovulation Protocol and Embryo Collection}

P36/L60 superovulation protocol, developed by (Baruselli et al., 2006; Moraes et al., 2007), was used. This protocol started on day 0 with the placement of an intravaginal device (CIDR® Pfizer Lab), filled with 0.5 $\mathrm{g}$ of natural progesterone, plus an Intramuscular (IM) injection of estradiol benzoate at a dose of $2.5 \mathrm{mg}(\mathrm{EB}$; Ric-Be, Syntex SA, Argentina), 600 IU of FSHp and 600 IU of LHp (Pluset ${ }^{\circledR}$ Calier Lab, Spain) in four days, with decreasing applications at $12 \mathrm{~h}$ intervals, two doses of cloprostenol sodium (Estrumate ${ }^{\circledR}$ Schering- Plough $\mathrm{Lab}$ ), each dose of $750 \mathrm{mcg}$, one in the morning and one in the afternoon on day 6 and the device was removed on day 7. After five days of the beginning of Superovulation (SO), estrus was detected and animals were inseminated at 12, 24 and $36 \mathrm{~h}$ post estrus, with a commercial semen of proven fertility (belonging to the same breed). On day $8,0.25 \mathrm{mg}$ of a synthetic GnRH gonadorelin analog (Fertagyl® Intervet Lab) was applied. On day 15 of treatment, embryo collection was carried out by uterine lavage with a two-way catheter. On this same day, the biological material obtained in filters was evaluated and an intramuscular injection of $750 \mathrm{mcg}$ of cloprostenol sodium (Estrumate $®$ Schering-Plough Lab) was administered (Fig. 1). 
Table 1: Composition of experimental diets (DM)

\begin{tabular}{|c|c|c|c|}
\hline \multirow[b]{2}{*}{ Ingredients } & \multicolumn{3}{|c|}{ Chemical composition (\%) } \\
\hline & Supplement & Piptocoma discolor & Brachiaria decumbens \\
\hline Dry matter, \% & 89.81 & 28.86 & 27.99 \\
\hline Ashes $\%$ & 3.80 & 8.17 & 7.31 \\
\hline Ether extract, $\%$ & 6.98 & 3.95 & 1.95 \\
\hline Crude protein, $\%$ & 11.78 & 21.51 & 6.33 \\
\hline Crude Fiber, $\%$ & 4.38 & 8.63 & 33.97 \\
\hline ME Mjul kgDM ${ }^{-1}$ & 11.76 & 10.26 & 6.63 \\
\hline DM digestibility & & 74.71 & \\
\hline DM degradability & 81.58 & & 53.92 \\
\hline Ingredient & & Quantity (\%) & \\
\hline Piptocoma discolor & & 20.00 & \\
\hline Corn meal & & 43.00 & \\
\hline Soy bean cake & & 0.20 & \\
\hline Corn bran & & 30.30 & \\
\hline Palm oil & & 0.50 & \\
\hline Molasses & & 5.00 & \\
\hline Microminerals a & & 1.00 & \\
\hline
\end{tabular}

${ }^{a}$ Micromineral premix content: Magnesium 10\%, zinc 10\%, iron 10\%, copper 2\%, iodine $0.12 \%$, selenium $0.06 \%$ and cobalt $0.02 \%$. DM: Dry Matter

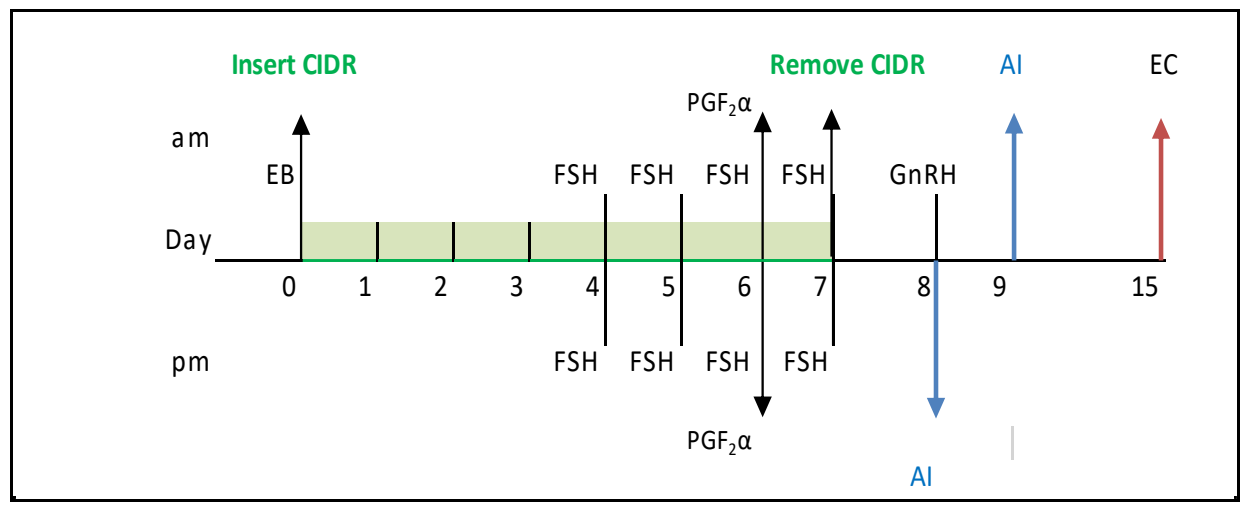

Fig. 1: Superovulation protocol and treatments

\section{Embryo Collection}

Embryos were collected seven days after heat was detected. Donors were placed in a restrain cage, where dorsal coccygeal and perivulvar areas were cleaned and disinfected, applying between 5 and $8 \mathrm{~mL}$ of $2 \%$ lidocaine epidurally. A two-way Foley catheter was vaginally inserted, adjusting it in the horn curvature, to perform uterine infusion-collections. An amount of $1.5 \mathrm{~L}$ of phosphate buffer solution was used, PBS with penicillin $\left(100 \mathrm{mg} \mathrm{mL}^{-1}\right)$ and streptomycin $(100 \mathrm{mg}$ $\left.\mathrm{mL}^{-1}\right) \quad\left(\right.$ ViGro $^{\mathrm{TM}} \quad$ Complete Flush Solution $\left.{ }^{\circledR}\right)$ (Dulbecco and Vogt, 1954).

\section{Embryo Search and Evaluation}

On embryo collection day (day 15) and on insemination day (day 8), the number of follicles and corpora lutea were determined by rectal palpation, respectively. Once the lavage of each donor was completed, filter content was placed in a $100 \times 100 \mathrm{~mm}$ square Petri dish with a gridded background and put in a reflected light stereo microscope with a magnification range from 6.7 to $45 \mathrm{X}$, for searching embryos. A 35-mm Petri dish was prepared with a maintenance solution (Syngro tm Holding. Bioniche ${ }^{\circledR}$ ) to place collected embryos. Selection and classification of collected structures (embryos and oocytes) were performed following the procedure indicated by the International Embryo Transfer Society (IETS) (Stringfellow and Seidel, 1998).

Embryos were classified according to their development stage, on a scale from 1 (one cell stage) to 9 (hatched blastocyst stage) and according to their quality as 1 (excellent), 2 (good), 3 (fair) and 4 (degenerate) (Phillips and Jahnke, 2016). For cryopreservation, morula and blastocyst stage embryos with qualities 1 and 2 were placed in a freezing medium with $10 \%$ ethylene glycol and $0.3 \mathrm{M}$ sucrose and placed into French straws (Baruselli et al., 2015). 


\section{Variables, Treatments and Periods}

Evaluated response variables were Number of Structures (NS), Transferable Embryos (TE), number of Non-Transferable Embryos (NTE), number of Corpora Lutea (CL), number of Follicles (F) and extraction percentage $(\% \mathrm{E})=($ Number of embryos/CL $) * 100$ and embryonic quality. Treatments consisted of T1: Without Supplementation (WS), T2: Supplementation, 42 days Before Protocol (SBP), T3: 42 days of Supplementation, 26 days Before and 16 days During Protocol (SBDP).

\section{Economic Analysis}

The evaluation was carried out using the partial budgeting technique, which allows to measure direct economic impact of the technological alternative that is intended to be implemented through the relationship between costs and incomes generated by it, compared to the technology that is to be replaced or improved (Mendieta, 1996).

\section{Statistical Analysis}

Three groups of animals were used, six replicates each, which were selected from a group of 30 animals. For the variables number of follicles, number of collected embryos and corpora lutea, a non-parametric (Kruskal and Wallis, 1952) analysis of variance was used, according to a completely randomized design. For the comparison of mean ranges, (Conover, 1999) test was applied for $\mathrm{p}<0.05$. For variables TE, NTE and quality of the stages in early morula, morula and blastocysts, a Chi-square comparison proportion analysis
(Font et al., 2007) was performed and (Duncan, 1995) test was applied for $\mathrm{p}<0.05$, in the necessary cases. The statistical program InfoStat (Di Rienzo et al., 2012) was used for processing information.

\section{Results}

\section{Number of Follicles and Corpus Luteum}

Table 2 shows results of the effect of supplementation period. No differences were detected among treatments under evaluation. Biological responses of follicles and corpora lutea were in the range of 6.17 to 8.33 and 5.5 to 7.17, respectively. These results were similar to those reported by (Acosta et al., 2016), who determined the effects of methionine and choline supplementation during prepartum and postpartum periods in embryos before their implantation in Holstein cows.

Results regarding number of structures demonstrated that there were no differences among supplementation periods, with means from 2.0 to $3.0(\mathrm{p}=0.6456)$ structure treatment ${ }^{-1}$. This agrees with reports of (Estrada, 2018), who studied estimated means of structures for seven breeds of native cattle, which ranged between 0.3 and 3.9 viable embryos.

Regarding percentage of extraction, there are no statistical differences among supplementation periods, with means between 38.63 and $42.22(p=0.5779)$. In this sense, response capacity to nutritional programs increases when animal requirements of these programs are fulfilled, depending on soil-plant-animal relationship (Silva et al., 2016).

Table 2: Response of native Hartón del Valle heifers to supplementation

\begin{tabular}{|c|c|c|c|c|}
\hline $\begin{array}{l}\text { Treatment } \\
\text { Variables } \\
\end{array}$ & $\begin{array}{l}\text { Without } \\
\text { supplementation }\end{array}$ & $\begin{array}{l}\text { Supplementation } \\
\text { before the period }\end{array}$ & $\begin{array}{l}\text { Supplementation before } \\
\text { and during the period }\end{array}$ & Sign. \\
\hline \multirow[t]{2}{*}{ Follicles } & $7.92(6.33)$ & $7.50(6.17)$ & $13.08(8.33)$ & $\mathrm{p}=0.1220$ \\
\hline & $\mathrm{SD}=1.97$ & $\mathrm{SD}=2.23$ & $\mathrm{SD}=1.75$ & \\
\hline \multirow[t]{2}{*}{ Structures } & $11.08(3.00)$ & $8.33(2.00)$ & $9.08(2.50)$ & $\mathrm{p}=0.6456$ \\
\hline & $\mathrm{SD}=1.26$ & $\mathrm{SD}=2.00$ & $\mathrm{SD}=2.74$ & \\
\hline \multirow[t]{2}{*}{ CL } & $7.58(5.50)$ & $8.00(5.67)$ & $12.92(7.17)$ & $\mathrm{p}=0.1460$ \\
\hline & $\mathrm{SD}=1.64$ & $\mathrm{SD}=2.07$ & $\mathrm{SD}=1.17$ & \\
\hline \multirow[t]{2}{*}{$\%$ Extraction } & $11.33(58.33)$ & $8.75(42.22)$ & $8.42(38.63)$ & $\mathrm{p}=0.5779$ \\
\hline & $\mathrm{SD}=26.67$ & $\mathrm{SD}=46.51$ & $\mathrm{SD}=42.56$ & \\
\hline
\end{tabular}

() General means SD: Standard Deviation

Table 3: Embryo production in native Hartón del Valle heifers

\begin{tabular}{|c|c|c|c|c|c|c|}
\hline \multirow[b]{2}{*}{ Treatment } & \multicolumn{2}{|c|}{ Transferable embryos } & \multicolumn{2}{|c|}{ Non-transferable embryos } & \multicolumn{2}{|c|}{ Total structures } \\
\hline & No. & $\%$ & No. & $\%$ & No. & $\%$ \\
\hline WS & 10 & 31.25 & 8 & $61.54^{\mathrm{a}}$ & 18 & 40.00 \\
\hline SBP & 9 & 28.12 & 3 & $23.08^{b}$ & 12 & 26.67 \\
\hline SBDP & 13 & 40.63 & 2 & $15.38^{\mathrm{b}}$ & 15 & 33.33 \\
\hline SE and Signif. & \multicolumn{2}{|c|}{ $\pm 8.33 \mathrm{p}>0.05$} & \multicolumn{2}{|c|}{ $\pm 13.07 \mathrm{p}<0.05$} & \multicolumn{2}{|c|}{ $\pm 7.03 p>0.05$} \\
\hline Total & 32 & 100 & 13 & 100 & 45 & 100 \\
\hline
\end{tabular}

a.b.c: Different letters per column indicate significant differences for $\mathrm{p}<0.05$; WS: Without Supplementation, SBP: Supplementation Before the Period, SBDP: Supplementation Before and During the Period 


\section{Transferable Embryos}

Proportion of transferable embryos, non-transferable embryos and total structures, obtained by the collection in each treatment (Table 3), indicate that TE percentage per treatment, regarding total TE, showed no difference among them, ranging between 28.13 and $40.63 \%$. However, NTE proportion, with respect to total, was lower $(\mathrm{p}<0.05)$ in supplemented treatments, regardless of the period in which it was carried out.

The aforementioned could be favored by supplementation, which provided an energy balance from transfer up to recovery of embryos in cattle, as proposed by (Shorten et al., 2018). In addition, it is stated that cows with higher energy balance have lower embryo losses (Obeidat et al., 2019).

Figure 2 shows results of the excellent quality of collected structures. It demonstrates that, when supplementing in both protocol phases, early morulae and blastocyst proportions were increased $(\mathrm{p}<0.05)$.

While in morulae, there were no differences among studied treatments. Snider et al. (2019) used a registered nutritional supplement and the results indicated an improvement of embryo quality and a decrease of nontransferable embryos, with a supplementation period of 49 days, before embryo collection.

Results of the current research were consistent with those reported by (Sales et al., 2015), who studied Bos Taurus and Bos indicus donor cows, fed a maintenance diet (maintenance energy and 1.7 higher than maintenance), 21 days before the beginning of superovulation protocol. Bos indicus cows, with a higher energy diet, had better oocyte quality and superior number of viable oocytes.

\section{Economic Evaluation}

Table 4 shows the economic evaluation. Expenses for superovulation inputs represent between 72.0 and $86.1 \%$ of total expenses. Supplementation expenses represented $17 \%$ of total expenses in the treatments in which supplementation was use in any of the stages.

Profits increased by 1.53 and 2.05 times when comparing supplementation treatments in both stages and non-supplementation.

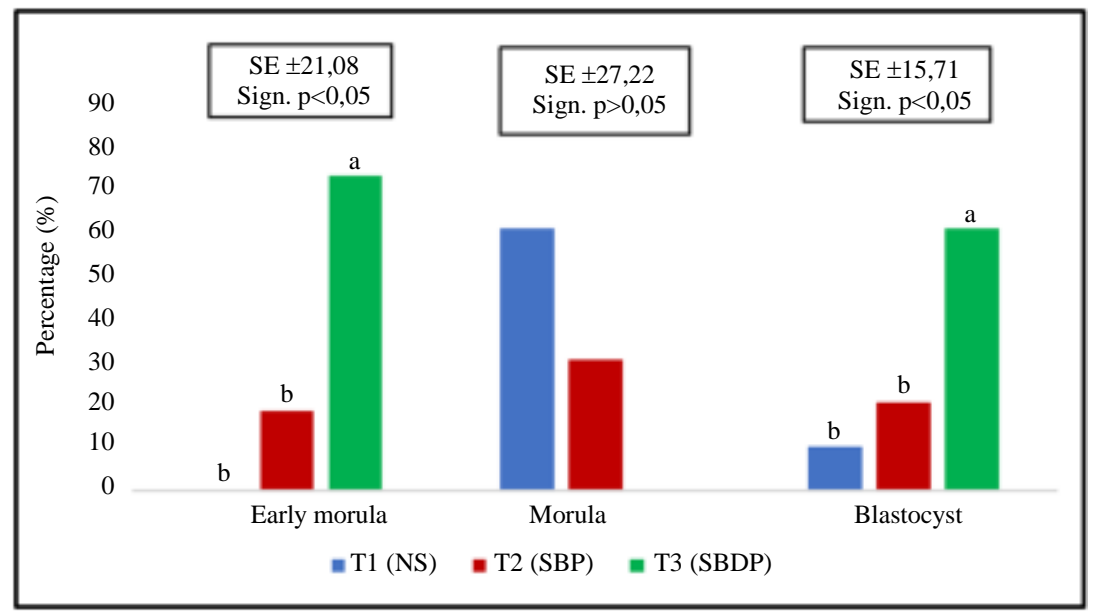

Fig. 2: Excellent embryonic quality per treatment; ${ }^{a, b}$ : Different letters indicate significant differences for $\mathrm{p}<0.05$

Table 4: Economic analysis of embryo production, according to supplementation periods with $20 \%$ of Piptocoma discolor

\begin{tabular}{|c|c|c|c|}
\hline \multirow[b]{2}{*}{ Indicators } & \multicolumn{3}{|c|}{ Treatments } \\
\hline & $\mathrm{T} 1$ & $\mathrm{~T} 2$ & $\mathrm{~T} 3$ \\
\hline \multicolumn{4}{|l|}{ Expenditure } \\
\hline Supplement intake $\left(\mathrm{kg}\right.$ heifer $\left.{ }^{-1}\right)$ & 0 & 29,40 & 29,40 \\
\hline Total expenses of food (\$) & 6.5 & 6.5 & 6.5 \\
\hline Total input expenses $\left(\right.$ \$heifer $^{-1}$ ) & 124,50 & 124,50 & 124,50 \\
\hline Labor expenses $\left(\$\right.$ heifer $\left.^{-1}\right)$ & 12.50 & 12.50 & 12.50 \\
\hline Total cost $\left(\$\right.$ heifer $\left.^{-1}\right)$ & 143.58 & 172,98 & 172,98 \\
\hline Total transferable embryo heifer ${ }^{-1}$ & 1.67 & 1.5 & 2.17 \\
\hline Total cost $\left(\$\right.$ embryo $\left.^{-1}\right)$ & 85.98 & 115.32 & 79.71 \\
\hline \multicolumn{4}{|l|}{ Income } \\
\hline Transferable embryo sale income (\$) & 334.0 & 300.0 & 434.0 \\
\hline Profit $(\$)$ & 190.42 & 127,02 & 261.02 \\
\hline Cost/benefit relationship & 2.33 & 1.73 & 2.51 \\
\hline
\end{tabular}


This favored the increase of cost/benefit relationship in 7.72 and $45.09 \%$, after comparing the same treatments.

\section{Discussion}

Regarding the number of structures (González et al., 2017), found that the measured ovulatory response in heifers and found an average of $2.0 \pm 1.1$ embryos per animal. Supplementation favors the response to number of follicles (Occhio et al., 2019), which could be related to changes in dry matter intake or during the supplementation period (Kumar and Laxmi, 2015) and this may propitiate an early embryonic development (Meléndez and Bartolomé, 2017).

These results were consistent with those reported by Molina-Coto et al. (2018). In that study, $300 \mathrm{~mL}$ of Propylene Glycol (PPG) were orally provided per day at the beginning of superovulation protocol. It was inferred that, despite PPG was a gluconeogenic supplement and ovaries were glucodependent, PPG supplementation did not affect the amount of collected embryos and follicles (Pérez-Clariget et al., 2017; Ribeiro, 2018). Results of the experiment suggested that other factors unrelated to the effect of supplementation, affected animal response to superovulation and embryo collection treatments (Ruiz et al., 2017).

Another factor was breed, which affects embryonic development during in vitro production, with the use of Swedish red breed as oocyte donors, there were differences with red Holstein regarding percentage of blastocysts (Ballesteros et al., 2017). Results of different studies showed that crosses and Scandinavian red breeds had better fertility than pure Holstein breed (Heins et al., 2006; Aguilar et al., 2018). This performance in native cattle could increase circulating glucose concentrations (Leane et al., 2018), which are positively associated with ovulation rates and in vivo follicular growth and, therefore, with a greater number of transferable embryos (Guanga et al., 2020; Laskowski et al., 2016).

For Chagas et al. (2007) sated that one of the reasons no significant differences were obtained in PPG supplementation, despite a different biological response, was that donors maintained an adequate base nutrition and body condition during the experiment. This limited the response to any supplement. However, improvement was achieved when it was provided to animals with low body condition. These studies were consistent with Hurley and Doane, (1989), who found that superovulated cows with an optimal feeding scheme, supplemented with selenium, showed $100 \%$ of fertilized structures, compared to $41 \%$ of fertilized egg cells in non-supplemented cows.

Likewise, Abuelo et al. (2015) evaluated the response of Angus heifers to superovulation protocols, which were fed mineral mixtures from organic and inorganic sources for 23 days with respect to a non-supplemented group (C). Although similar amounts of TE were collected per treated heifer, animals of the group of organic sources averaged 0.44 NTE per female treated at the time of collection, which were lower values than those found in the current experiment. Published information indicates that populations of native cattle have, as an average, lower number of transferable embryos than those obtained from other breeds (Mikkola et al., 2020; Robinson et al., 2019).

At the beginning of supplementation, an energy deficit compromises the high levels of urea, which can lead to changes that may produce infertility. This could alter the protein-energy relationship and be the cause of poor embryonic development (Crociati et al., 2017). This could explain the decrease of the number of nontransferable embryos with the use of supplementation (Summers et al., 2018; Kruse et al., 2016).

However, supplementation effects on embryo obtaining were contradictory. Thus, Hackbart et al., (2017) reported that supplementation with PPG reduced total ovulations and fertilization rate. This flexibility in the results of this experiment suggests that response of cows to multiovulation was affected by multiple factors, including paternal effect (Rani et al., 2018; Mikkola and Taponen, 2017; Chinchilla-Vargas et al., 2018). This fact makes difficult to evaluate animal response to a supplement. The supply of $2.0 \mathrm{~kg} \mathrm{MF}^{-1}$ of animal supplement ${ }^{-1} \mathrm{day}^{-1}$, with an effect on embryonic development, could improve physiological conditions of the animal (Perez et al., 2017; Gallego et al., 2017; Moscoso-Piedra and Cabrera, 2019; Kasimanickam et al., 2020).

Contrary to the findings of this study, for Serrano-Pérez (2020) found that undernourishment did not affect pregnancy in the first week of gestation, as well progesterone levels (Stephenson et al., 2018; Noya et al., 2020). Sartori et al. (2016) showed that Gyr cows had a decrease in blastocyst rate (46.9 Vs. 25.7\%) during dry period, in which a diet of 1.7 over the maintenance was offered, for more than 60 days. However, these authors concluded that blastocyst rate was the same in non-lactating Holstein cows before or after being overfed for more than 60 days.

Although oocyte intrinsic quality determines developmental competence, that is, oocyte proportion that becomes blastocysts, environmental conditions have a major impact on their quality (Cuevas et al., 2018; Tahuk et al., 2018). In fact, management conditions influence on the moment of embryonic development, as the first division, beginning of a superior genomic activation and blastocyst quality (Zullo et al., 2016; Gerger et al., 2017; Byrne et al., 2018).

On the other hand, the number of embryos in this study were low, compared to higher means in other breeds, possibly due to factors such as age and physiological status. Kenny et al. (2018); Krause et al., (2017) reported improvements in oocyte competition, 
fertilization and formation rates of blastocysts with the aging of animals.

According to Nieddu et al., (2015) it is probable that, with a severe nutritional restriction, with 0.6 of energy requirements for maintenance during the first 100 days of gestation, the number of antral follicles decreases in undernourished mothers.

Results of a 42-day supplementation with treatment 3 were similar to those of Gardinal et al. (2018). These authors evaluated different durations of Whole raw Soybeans (WS) supplementation during prepartum period in embryo quality of transition cows. All groups receiving WS during prepartum period showed the highest value in embryonic quality. As stated by Santos et al. (2016), a gluconeogenic and protein source helps the complete metabolism of glucose that favors reproduction. In turn, blastocyst morphology and its quality are related to glucose consumption. Thus, blastocyst low quality is associated with a lower glucose consumption and the high amount of energy in the diet increases insulin receptors and excesses affect the development of blastocysts (Gobikrushanth et al., 2018).

Studies conducted on humans used C13 fatty acids in hours after culture (when the embryo has 8 cells or more). They improved embryonic quality, which was more important in the final development stages because it stimulates protein kinase $\mathrm{C}$, essential for cell differentiation and growth (Gardner et al., 2011).

Melatonin supplementation reduced apoptosis, increased the proportion of Inner Cell Mass (ICM) to total cells and improved the development of bovine embryos generated via Somatic Cell Nuclear Transfer (SCNT) both in vitro and in vivo. Moreover, global H3 acetyl lysine 9 (H3K9ac) level was significantly elevated in the melatonin-treated SCNT group, indicating that the addition of melatonin may affect nuclear reprogramming, resulting in improved blastocyst quality (Yun-Wei et al., 2018). However, Yun-Wei et al., (2018) stated that flushing only during the period prior to insemination is insufficient and that it should be maintained for at least 21 days after insemination for a positive effect on fertility through ovarian activation (López-Gatius et al., 2017).

Results of the current study agree with Gamarra et al. (2018), who observed a strong positive relationship among circulating levels of Anti-Müllerian Hormone $(\mathrm{AMH})$ and in vivo embryo production after superovulation in cattle. In this regard, nutritional factors, which can be balanced by supplementation, seem to influence plasma AMH levels (Souza et al., 2015; Baruselli et al., 2011), which positively influences on the number of excellent quality embryos in embryo transfer programs.

Values referred in the current study could be related to the amounts of amino acids due to the effect of the microbial protein, according to studies of Chavatte-Palmer et al. (2018). For authors like Stokes et al., (2017), total protein concentration in the follicular fluid was an indicator of the quality of the oocyte, expression, presentation and concentration of different proteins, which varied with follicle size. Furthermore, fluid composition influenced on oocyte quality. Several studies agree that factors associated with good embryonic quality require simple carbohydrates, pyruvate, ATP, microminerals, antioxidants and vitamins (López-Velázquez et al., 2019; Cajas et al., 2019; Torres Osorio et al., 2019; Abdelatty et al., 2018; Agarwal et al., 2018).

Regarding the economic the costs of embryo transfer technique, it was only suitable for registered pure herds or for genofund conservation (Naranjo-Chacón et al., 2016).

Nevertheless the costs of this study are higher than those reported by Castaño (2016) with a conventional embryo transfer protocol and without supplementation with $\$ 50.85$ per embryo. These costs are relatively low, since Bos taurus breed was used, in which the average number of embryos was higher. This increased cost/benefit relationship by achieving a better embryonic response by hormonal methods (Baracaldo Camargo, 2018).

It was recently determined that orally administered propylene glycol to Holstein heifers increased the number of follicles and blastocyst quality of heifers having higher plasma Anti-Müllerian Hormone (AMH) levels. Therefore, measuring AMH before applying FSH programs to cows will allow professionals to increase the number of produced embryos and thus, reduce costs per produced embryo (Sánchez-Castro, 2017).

\section{Conclusion}

Supplementation to Hartón del Valle heifers, before and during superovulation, favored the biological response of collected structures, number of follicles and corpora lutea. Similarly, the proportion of transferable embryos, early morulae and quality one blastocytes increased, in addition to achieving a higher cost/benefit relationship.

\section{Acknowledgement}

Authors are grateful to the administrator Rosa Amelia Quiroz, for the field support and to the technicians Jenny Riascos and Lina Yurany Quintero for the field work. Thanks also to the Biotechnology Laboratory, National Learning Service, SENNOVA project, Putumayo Regional. Thanks also to Norbery Gutierrez and Luz Mary Ortiz for handling lab equipment, Agricultural Center of Buga, SENA Regional Valley. 


\section{Funding Information}

This research had the financing of $80 \%$ of the resources of the National Learning Service SENA; with SENNOVA projects presented by innovation and research lines. Call validity 2018.

\section{Author Contributions}

All authors equally contributed in this work.

\section{Conflict of Interest}

The authors have no personal financial or nonfinancial competing interest in the product.

\section{Data Availability Statement}

Datasets generated for this study are available on request to the corresponding author.

\section{Contribution to Field Declaration}

In many species, local genetic resources are indiscriminately crossed with foreign breeds, leading to a reduction or extinction of locally adapted breeds that are promising to adjust to climate change. Native animals demonstrate their ability to survive despite very precarious and inhospitable conditions, such as those found at the time of their introduction by conquistadors. In addition, it is demonstrated that small existing native groups of animals have a high diversity degree, which indicates a great genetic potential for selection and crossing to produce crossbred animals for their inclusion in the milk and meat production chain. The conservation of genetic resources of native breeds, through embryo collection and diet improvement of supplementation with forages from the Amazonian piedmont, is theoretically important for having updated information regarding the use of local resources for bovine feeding and ovarian activation, in order to increase the production of quality embryos and improve gestation rates.

\section{References}

Abdelatty, A. M., Iwaniuk, M. E., Potts, S. B., \& Gad, A. (2018). Influence of maternal nutrition and heat stress on bovine oocyte and embryo development. International Journal of Veterinary Science and Medicine, 6(January), S1-S5. https://doi.org/10.1016/j.ijvsm.2018.01.005

Abuelo, A., Benedito, J. L., \& Castillo, C. (2015). The importance of the oxidative status of dairy cattle in the periparturient period: revisiting antioxidant supplementation. Journal of Animal Physiology and Animal Nutrition, 99, 1003-1016. https://doi.org/10.1016/j.theriogenology.2016.01.024
Acosta, D. A. V., Denicol, A. C., Tribulo, P., Rivelli, M. I., Skenandore, C., Zhou, Z., Luchini, D., Corrêa, M. N., Hansen, P. J., \& Cardoso, F. C. (2016). Effects of rumen-protected methionine and choline supplementation on the preimplantation embryo in Holstein cows. Theriogenology, 85(9), 1669-1679. https://pubmed.ncbi.nlm.nih.gov/26928647/

Agarwal, A., Sengupta, P., \& Durairajanayagam, D. (2018). Role of L-carnitine in female infertility. Reproductive Biology and Endocrinology, 16(5), 1-19. https://doi.org/10.1186/s12958-018-0323-4

Aguilar, L., Aguilar, N., Nieto, P., Rodas, R., Dutan, J., Murillo, Y., Vázquez, J., \& Samaniego, J. (2018). Efecto de la grasa bypass sobre la reactivación ovárica postparto en vacas Holstein friesian mestizas con condición corporal diferente - Effect of bypass fat on ovarian reactivation post-partum in Holstein friesian cows with different body condition. REDVET. Revista Electrónica de Veterinaria, 1(Cc), 1-13.

AOAC. (2016). Official methods of analysis of AOAC. International. 20. ed. ed., Rockville MD: AOAC International, Latimer George W. Jr. ISBN: 0309069971.

Ariza-Nieto, C., Mayorga, O. L., Mojica, B., Parra, D., \& Afanador-Tellez, G. (2018). Use of LOCAL algorithm with near infrared spectroscopy in forage resources for grazing systems in Colombia. Journal of Near Infrared Spectroscopy, 26(1), 44-52. https://doi.org/10.1177/0967033517746900

Ballesteros, B. H. B., Tribulo, H. E., Mutto, A. A., \& Bo, G. A. (2017). Influencia de la suplementación del medio de cultivo con ácido linoleico en la supervivencia a la congelación de embriones bovinos in Vitro. Revista Electronica de Veterinaria, $18(11)$. https://www.redalyc.org/pdf/636/63653574020.pdf

Baracaldo Camargo, A. D. (2018). Suplementación estratégica para mejorar la producción de ovejas en trópico bajo colombiano. In Ciencia Unisalle. https://ciencia.lasalle.edu.co/cgi/viewcontent.cgi?art icle $=1359 \&$ context $=$ zootecnia

Baruselli, P., de Sá Filho, M., Martins, C., Nasser, L., Nogueira, M., Barros, C., \& Bó, G. (2006). Superovulation and embryo transfer in Bos indicus cattle. Theriogenology, 65, 77-88. https://doi.org/10.1016/j.theriogenology.2005.10.006

Baruselli, P. S., Ferreira, R. M., Sales, J. N. S., Gimenes, L. U., \& Filho, M. F. S. (2011). Timed embryo transfer programs for management of donor and recipient cattle. 76, 1583-1593. https://doi.org/10.1016/j.theriogenology.2011.06.006

Baruselli, P. S., Marques, M. O., Vieira, L. M., Konrad, J. L., \& Crudeli, G. A. (2015). Aplicación de biotecnologías para una mayor producción de terneros. Revista Veter, 26(2), 154-159. https://doi.org/10.30972/vet.262231 
Borge, S., Kull, O. H., Krogenæs, A. K., \& Oskam, C. I. (2019). Possibilities And Challenges Related to Norwegian Embryo Production in Cattle. NMBU Veterinærhøgskolen Fakultet for Veterinærmedisin Og Biovitenskap Institutt for Produksjonsdyrmedisin Fordypningsoppgave, 1-53.

Buerkle, T. (2007). FAO sounds alarm on loss of livestock breeds. Food and Agriculture Organization of the United Nations. http://www.fao.org/

Byrne, C. J., Fair, S., English, A. M., Urh, C., Sauerwein, H., Crowe, M. A., \& Lonergan, P. (2018). Plane of nutrition before and after 6 months of age in HolsteinFriesian bulls: II. Effects on metabolic and reproductive endocrinology and identification of physiological markers of puberty and sexual maturation. Journal Dairy Science, 101, 3460-3475. https://doi.org/10.3168/jds.2017-13720

Cajas, Y. N., Cañón-Beltrán, K. E., González, M. E., \& Dimitrios, R. (2019). Interacciones maternoembrionarias preimplantacionales en la especie bovina. Revista Ecuatoriana de Ciencia Animal, $3(2)$, 39-68.

http://www.revistaecuatorianadecienciaanimal.com/i ndex.php/RECA/article/view/117

Calderón, P., Fabian, M., Bosa, P., Fernanda, L., Yasnó, C., Diego, J., Saldaña, M., \& Yurany, L. (2017). Relación nutrición-fertilidad en hembras bovinas en clima tropical. REDVET. Revista Electrónica de Veterinaria, 18(9), 1-19. https://www.redalyc.org/pdf/636/63653009019.pdf

Cardona-Iglesias, J. L., Mahecha-Ledesma, L., \& Angulo-Arizala, J. (2016). Arbustivas forrajeras y ácidos grasos: estrategias para disminuir la producción de metano entérico en bovinos. Agronomía Mesoamericana, 28(1), 273. https://doi.org/10.15517/am.v28i1.21466

Castaño, G. (2016). Efecto de un priming con progesterona dos días adicionales en un protocolo de superovulacion convencional sobre la respuesta embrionaria en vacas raza Blonde D'Aquitaine. Universidad de Cundinamarca, 86. http://repositorio.ucundinamarca.edu.co/handle/20.5 $00.12558 / 321$

Chagas, L., Bass, J., Blache, D., Burke, C., Kay, J., \& Lindsay, D. (2007). Invited re- view: new perspectives on the roles of nutrition and metabolic priorities in the subfertility of high-producing dairy cows. Journal Dairy Science, 90, 4022-4032. https://doi.org/10.3168/jds.2006-852

Chavatte-Palmer, Velazquez, M. A., Jammes, H., \& Duranthon, V. (2018). Review: Epigenetics, developmental programming and nutrition in herbivores. The Animal Consortium, 363-371. https://doi.org/10.1017/S1751731118001337
Chen, X., Ørskov, E., \& Howell, F. D. B. (1990). Excretion of purine derivatives by ruminants: endogenous excretion, difference between cattle and sheep. British Journal of Nutrition, 63, 121. https://doi.org/10.1079/BJN19900097

Chinchilla-Vargas, J., Jahnke, M. M., Dohlman, T. M., Gunn, P., \& Rothschild, M. F. (2018). Climatic Factors Affecting Quantity and Quality Grade of in vivo Produced Bovine Embryos. 664. https://doi.org/10.31274/ans_air-180814-406

Conover, W. (1999). Practical Nonparametric Statistcs, John Wiley and Sons.

Crociati, M., Sylla, L., Floridi, C., Comin, A., Fruganti, G., Monaci, M., \& Stradaioli, G. (2017). Influence of lipoproteins at dry-off on metabolism of dairy cows during transition period and on postpartum reproductive outcomes. Theriogenology, 94, 31-36. https://doi.org/10.1016/j.theriogenology.2017.02.007

Cuevas, I., Carme, M., Gatell, P., Cuadros, M., Delgado, A., Rives, N., Moragas, M., Victoria, M., \& Mendoza, H. De. (2018). Medicina Reproductiva y Embriología Clínica The Embryology Interest Group: updating ASEBIR's morphological scoring system for early embryos, morulae and blastocysts. Medicina Reproductiva y Embriología Clínica, 5(1), 42-54. https://doi.org/10.1016/j.medre.2017.11.002

Di Rienzo, J., Casanoves, F., Balzarini, M., Gonzalez, L., Tablada, M., \& Robledo, C. (2012). InfoStat versión. Grupo InfoStat, FCA, Universidad Nacional de Córdoba, Argentina. http://www.infostat.com.ar

Dulbecco, R., \& Vogt, M. (1954). Plaque formation and isolation of pure lines with poliomyelitis viruses. Journal of Experimental Medicine, 99, 167-182. https://doi.org/10.1084/jem.99.2.167

Duncan, D. B. (1955). Multiple range and multiple F tests. Biometrics, 11(1), 1-42. https://doi.org/10.2307/3001478

Estrada, J. (2018). Superovulatory response of Colombian Creole cattle to two doses of FSH. Theriogenology, 49(January), 377-382. https://doi.org/10.1016/S0093-691X(98)90730-0

Font, H., Noda, A., Torres, V., Herrera, M., Lizazo, D., Sarduy, L., \& Rodríguez, L. (2007). Compar Pro versión 1. Inst Ciencia Animal, Dpto Biomatemática.

Gallego, C., Peñalver, A., García, A., Méndez, M., Inés, M., Souza, L., Oba, E., \& García, R. (2017). Influence of the physiological state on the energy, protein and endocrine metabolism, in Siboney de Cuba cows Influencia del estado fisiológico en el metabolismo energético, proteico y endocrino, en vacas Siboney de Cuba. Cuban Journal of Agricultural Science, 51(4), 427-432. https://www.redalyc.org/pdf/1930/193057230004.pdf 
Gamarra, G. A., Ponsart, C. C., Lacaze, S. B., Nuttinck, F. D., \& Cordova, A. E. (2018). Oral propylene glycol modifies follicular fluid and gene expression profiles in cumulus - oocyte complexes and embryos in feed-restricted heifers. 417-429. https://doi.org/10.1071/RD17037

Gardinal, R., Calomeni, G. D., Zanferari, F., Vendramini, T. H. A., Takiya, C. S., Del Valle, T. A., \& Renno, F. P. (2018). Different durations of whole raw soybean supplementation during the prepartum period: Milk fatty acid profile and oocyte and embryo quality of early-lactating Holstein cows. Journal of Dairy Science, 101(1), 675-689. https://doi.org/10.3168/jds.2016-12504

Gardner, D., Wale, P., Collins, R., \& Lane, M. (2011). Glucose consumption of single post-compaction human embryos is predictive of embryo sex and live birth outcome. Hum Reprod, 26, 1981-1986. https://doi.org/10.1093/humrep/der143

Gerger, R. P. C., Rossetto, R., Ribeiro, E. S., Ortigari, I., Zago, F. C., Aguiar, L. H., Costa, U. M., Lopes, R. F. F., Ambrósio, C. E., Miglino, M. A., Rodrigues, J. L., Forell, F., Bertolini, L. R., \& Bertolini, M. (2017). Impact of cumulative gain in expertise on the efficiency of handmade cloning in cattle. Theriogenology, 95, 24-32. https://doi.org/10.1016/j.theriogenology.2017.02.025

Gobikrushanth, M., Purfield, D. C., Colazo, M. G., Wang, Z., Butler, S. T., \& Ambrose, D. J. (2018). The relationship between serum insulin-like growth factor-1 (IGF-1) concentration and reproductive performance and genome-wide associations for serum IGF-1 in Holstein cows. J. Dairy Sci., 1(191), 9154-9167. https://doi.org/10.3168/jds.2018-14535

González, F. V., De La Torre Sánchez, J. F., Velázquez, G. M., Gallardo, H. Á., Reynozo, S. P., Fránquez, J. A. P., Sojo, R. P., \& Bermúdez, M. M. (2017). Caracterización de la respuesta ovárica a la superovulación en bovino Criollo Coreño utilizando dosis reducidas de FSH. Revista Mexicana De Ciencias Pecuarias, 8(3), 225-232. https://doi.org/10.22319/rmcp.v8i3.4498

Guanga, L. A., Campoverde, J. S., Garzón, D. A., Brugal, M. P., Ganchou, F. P., Carpio, E. R., \& Escandón, P. N. (2020). El intervalo de tiempo entre la estimulación ovárica con FSH/LH y la colecta afecta la cantidad, calidad y capacidad de desarrollo de los ovocitos recuperados de novillas criollas ecuatorianas from Ecuadorian creole heifers. Rev Inv Vet Perú, 31(1), 1-11. https://doi.org/10.15381/rivep.v31i1.17571

Hackbart, K., Bender, R., Carvalho, P., Vieira, L., Dresch, A., \& Guenther, J. (2017). Effects of propylene glycol or elevated luteinizing hormone during follicle development on ovulation, fertilization and early embryo development. Biol. Reprod, 97, 550-63. https://doi.org/10.1093/biolre/iox050
Heins, B., Hansen, L., \& Seykora, A. (2006). Fertility and survival of pure Holsteins versus crossbred of Holstein with Normande, Montbeliarde and Scandinavian Red. Journal of Dairy Sciences, 89, 4944-4951. https://doi.org/10.3168/jds.S0022-0302(06)72545-0

Holdridge, Z. D. D. (1987). Determination of world plant formations from simple climatic data. Science, 105 ,

$367-368$ https://doi.org/10.1126/science.105.2727.367

Hurley, W., \& Doane, R. (1989). Recent developments in the roles ofvitamins an minerals in reproduction. J. Dairy Sci., 72, 784-804. https://doi.org/10.3168/jds.S0022-0302(89)79170-0

Ibtisham, F., Nawab, A., Li, G., Xiao, M. E. I., An, L., \& Naseer, G. (2018). Effect of nutrition on reproductive efficiency of dairy animals. Med. Weter., 74(6), 356-361. https://doi.org/10.21521/mw.6025

IDEAM. (2017). Estación seleccionada se ubica en las siguientes Coordenadas Geográficas: 04¹1' latitud Sur, 6956' longitud Oeste, elevación: $84 \mathrm{~m}$. La medición de precipitación se realiza con pluviómetros estánda. Instituto de Hidrología, Meteorología y Estudios Ambientales-Subdirección de Meteorología.

Kasimanickam, R., Kasimanickam, V., Kastelic, J. P., \& Ramsey, K. (2020). Metabolic biomarkers, body condition, uterine in $\mathrm{fl}$ ammation and response to superovulation in lactating Holstein cows. Theriogenology, 146, 71-79. https://doi.org/10.1016/j.theriogenology.2020.02.006

Kenny, D. A. A., Heslin, J. A., \& Byrne, C. J. A. (2018). Early onset of puberty in cattle: implications for gamete quality and embryo survival. 101-117. https://doi.org/10.1071/RD17376

Krause, A., Diaz, F., Adams, G., Mapletoft, R., Huanca, W., \& Zwiefelhofer, E. (2017). Antral follicular counts and superstimulatory response in prepubertal calves. Reprod. Fertil. Dev, 29, 210-128. https://doi.org/10.1071/RDv29n1Ab202

Kruse, S. G., Bridges, G. A., Funnell, B. J., Bird, S. L., Lake, S. L., Arias, R. P., Amundson, O. L., Larimore, E. L., Keisler, D. H., \& Perry, G. A. (2016). Influence of post-insemination nutrition on embryonic development in beef heifers. Theriogenology, 11, 1-24. https://pubmed.ncbi.nlm.nih.gov/28166966/

Kruskal, W., \& Wallis, W. (1952). Use of ranks in onecriterion variance analysis. Journal of the American Statistical Association, 47, 583-621. https://doi.org/10.1080/01621459.1952.10483441

Kumar, A., \& Laxmi, N. (2015). Role of IGF-1 in male and female reproduction in bovines: a review. Asia Pacific Journal of Research, 1, 17-25. https://www.researchgate.net/publication/32722153 4_ROLE_OF_IGF_1_IN_MALE_AND_FEMALE_ REPRODUCTION_IN_BOVINES_A_REVIEW 
Landínez-Torres, Y. Á. (2017). Soil use and management in the Colombian Amazon. Open Journal System, 12(2), 151-163. https://doi.org/10.21615/cesmvz.12.2.6

Larson, R. L., \& White, B. J. (2016). Reproductive Systems for North American Beef Cattle Herds. Veterinary Clinics of North America - Food Animal Practice, 32(2), 249-266. https://doi.org/10.1016/j.cvfa.2016.01.001

Laskowski, D., Sjunnesson, Y., Humblot, P., \&ersson, G., Gustafsson, H., \& Båge, R. (2016). The functional role of insulin in fertility and embryonic development-What can we learn from the bovine model? Theriogenology, 86(1), 457-464. https://doi.org/10.1016/j.theriogenology.2016.04.062

Leane, S., Herlihy, M. M., Curran, F., Kenneally, J., Forde, N., Simintiras, C. A., \& Sturmey, R. G. (2018). The effect of exogenous glucose infusion on early embryonic development in lactating dairy cows. Journal of Dairy Science, 1-12. https://doi.org/10.3168/jds.2018-14894

López-Gatius, F., \&reu-Vázquez, C., Mur-Novales, R., Cabrera, V. E., \& Hunter, R. H. F. (2017). The dilemma of twin pregnancies in dairy cattle. A review of practical prospects. Livestock Science, 197(October 2016), 12-16. https://doi.org/10.1016/j.livsci.2017.01.001

López-Velázquez, M., Miranda-Jiménez, L., QueroCarrillo, A., Robledo-Paz, A., \& Morales-Vidal, S. (2019). Leukocytes during embryonic development on ewes as a response to organic selenium. Abanico Veterinario, 9(December), 1-9.

Martínez, R. A. (2019). Contribución de la mejora genética animal a la resiliencia de los sistemas ganaderos. Cuban Journal of Agricultural Science, 53(2),

103-108.

http://scielo.sld.cu/scielo.php?script=sci_arttext\&pid $=$ S2079-34802019000200103

Mathios Flores, M., Alegre Orihuela, J., Aguilar Vásquez, J., \& Celis Pinedo, W. (2019). Reserva de carbono en hatos ganaderos y su relación ambiental socioeconómicos en la cuenca baja del río Shanusi Alto Amazonas - Loreto - Perú. Aporte Santiaguino, $10(2)$, 7-20. https://doi.org/10.32911/as.2019.v12.n1.604

Mehrez, A., \& Orskov, E. (1977). A study of the artificial bag technique for determining the digestibility of feeds in the rumen. J. Agric. Sci, 88, 645-650. https://doi.org/10.1017/S0021859600037321

Meléndez, P., \& Bartolomé, J. (2017). Avances sobre nutrición y fertilidad en ganado lechero: Revisión. Revista Mexicana De Ciencias Pecuarias, 8(4), 407-417. https://doi.org/10.22319/rmcp.v8i4.4160

Mendieta, B. (1996). Administración agropecuaria. Texto básico. Universidad Nacional Agraria. Managua, Nicaragua.
Mikkola, M., Hasler, J. F., \& Taponen, J. (2020). Factors affecting embryo production in superovulated Bos taurus cattle. Ivd, 104-124. https://doi.org/10.1071/RD19279

Mikkola, M., \& Taponen, J. (2017). Theriogenology Embryo yield in dairy cattle after superovulation with Folltropin or Pluset. Theriogenology, 88, 84-88. https://doi.org/10.1016/j.theriogenology.2016.09.052

Molina-Coto, R., Arroyo-oquendo, C., Carballoguerrero, D., \& Elizondo-salazar, J. A. (2018). Respuesta a la suplementación con propilenglicol en vacas multiovuladas, Propylene glycol supplementation response in multiovulated cows for embryo production. 29(3), 519-533. https://doi.org/10.15517/ma.v29i3.30837

Moniruzzaman, M., \& Miyano T. (2010). Growth of primordial oocytes in neonatal and adult mammals. $\mathrm{J}$ Reprod Dev, 56, 559-566. https://doi.org/10.1262/jrd.10-071H

Moraes, C., Cláudia, A., \& Marcelo, F. (2007). Atualidades na superovulação de doadoras Bos taurus e Bos indicus, Biotecnologia da reprodução em bovinos. 3 Simpósio Internacional de Reprodução Animal Aplicada.

Moscoso-Piedra, A., \& Cabrera, B. (2019). Efecto de tres niveles de la inclusión de grasa de sobrepaso sobre la ciclicidad ovárica de hatos lecheros en los Andes Ecuatorianos Effect of three levels of the inclusion of excess fat on the ovarian cyclicity of dairy herds in the Ecuadorian Andes. 9, 1-12. https://doi.org/10.21929/abavet2019.916

Naranjo-Chacón, F., Becerril-Pérez, C. M., CansecoSedano, R., Zárate-Guevara, O. E., Soto-Estrada, A., Rosales Martínez, F., \& Rosendo-Ponce, A. (2016). Comparación de dos métodos de transferencia de embriones en el ganado criollo lechero tropical. Ecosistemas y Recursos Agropecuarios, 3(7), 113-120. http://www.scielo.org.mx/scielo.php?pid=S2007$90282016000100011 \&$ script $=$ sci_arttext\&tlng=pt

Nieddu, S. M., Mossa, F., Strina, A., Ariu, F., Pau, S., Ledda, M., Sotgia, S., Carru, C., \& Ledda, S. (2015). Differences in amniotic amino acid concentrations between pregnancies obtained with transfer of vitrified thawed invitro-produced embryos and with natural mating in sheep. Theriogenology, 83(4), 687-692. https://doi.org/10.1016/j.theriogenology.2014.11.002

Noya, A., Casasús, I., Ferrer, J., \& Sanz, A. (2020). Domestic Animal Endocrinology A negative energy balance during the peri-implantational period reduces dam IGF-1 but does not alter progesterone or pregnancy-speci fi c protein B (PSPB) or fertility in suckled cows. Domestic Animal Endocrinology, 72 , 106-18. https://doi.org/10.1016/j.domaniend.2019.106418 
NRC. (2001). Nutrient Requirements of Dairy Cattle Seventh. cod. Nutrient Requirements of Dairy Cattle.

Obeidat, Y., Catandi, G., Carnevale, E., Chicco, A. J., DeMann, A., Field, S., \& Chen, T. (2019). A multisensor system for measuring bovine embryo metabolism. Biosensors and Bioelectronics, 126, 615-623. https://doi.org/10.1016/j.bios.2018.09.071

Occhio, M. J. D., Baruselli, P. S., Campanile, G., Occhio, M. J. D., Baruselli, P. S., \& Campanile, G. (2019). Metabolic health, the metabolome and reproduction in female cattle: a review. Italian Journal of Animal Science, 18(1), 858-867. https://doi.org/10.1080/1828051X.2019.1600385

Pérez-Clariget, R., Carriquiry, M., \& Soca, P. (2017). Estrategias de manejo nutricional para mejorar la reproducción en ganado bovino. Arch. Latinoam. Prod. Anim, 15, 114 - 119.

Perez, B. C., Balieiro, J. C. C., Ventura, R. V, Bruneli, F. A. T., \& Peixoto, M. G. C. D. (2017). animal Inbreeding effects on in vitro embryo production traits in Guzerá cattle. The Animal Consortium, 11(11), 1983-1990. https://doi.org/10.1017/S1751731117000854

Phillips, P. E., \& Jahnke, M. M. (2016). Embryo Transfer (Techniques, Donors and Recipients). Veterinary Clinics of NA: Food Animal Practice, 32(2), https://doi.org/10.1016/j.cvfa.2016.01.008

Prenteci, A., \& Anzar, M. (2011). Cryopreservation of mammalian oocyte for conservation of animal genetics. Veterinary Medicine International, 11. https://doi.org/10.4061/2011/146405

Rani, P., Dutt, R., Singh, G., \& Chandolia, R. K. (2018). Embryonic Mortality in Cattle- A Review. International Journal of Current Microbiology and Applied Sciences, 7(07), 1501-1516. https://doi.org/10.20546/ijcmas.2018.707.177

Riascos-Vallejos. A. R., Reyes, G. J. J., Valenciaga, Gutiérrez, D., \& Apráez, G. J. E. (2020a). Ruminal degradability of supplements based on three native forages and adapted to the Colombian Amazonian piedmont. Cuban Journal of Agricultural Science, 54(2),

193-207. https://www.scienceopen.com/document?vid=9f1b2 543-27d3-4ae5-a4f4-67eadabef417

Riascos-Vallejos. A., Reyes, G. J., \& Aguirre, M. LA. (2020b). Nutritional characterization of trees from the Amazonian piedmont. Cuban Journal of Agricultural Science, 54(2), 1-9. http://www.cjascience.com/index.php/CJAS/article/ view/951

Ribeiro, E. S. (2018). Symposium review: Lipids as regulators of conceptus development: Implications for metabolic regulation of reproduction in dairy cattle 1. Figure 2, 3630-3641. https://doi.org/10.3168/jds.2017-13469
Robinson, L., Gustavo, C., Gilberto, T., Alejandro, G., Juan, G., \& Robinson, L. (2019). Ovarian Follicular Dynamics in Caqueteño Creole Cattle Breed at the Colombian Amazon Piedmont. American Journal of Animal and Veterinary Sciences, 14(2), 101-110. https://doi.org/10.3844/ajavsp.2019.101.110

Rossetto, R., Saraiva, M. V. A., Bernuci, M. P., Silva, G. M., Brito, I. R., Alves, A. M. C. V., MagalhãesPadilha, D. M., Báo, S. N., Campello, C. C., Rodrigues, A. P. R., \& Figueiredo, J. R. (2016). Impact of insulin concentration and mode of FSH addition on the in vitro survival and development of isolated bovine preantral follicles. Theriogenology, 86(4), 1137-1145. https://doi.org/10.1016/j.theriogenology.2016.04.003

Ruiz, C. S., Góez, G. D., Herrera, L. A., \& Giraldo, G. J. (2017). Efecto del nivel de suplementación con propilenglicol durante el período de transición a la lactancia sobre actividad ovárica y desempeño reproductivo en vacas. Revista Lasallista de Investigación, $\quad 14(2), \quad 30-40$. https://doi.org/10.22507/rli.v14n2a3

Ruíz, R., \& Menchaca, M. (1990). Modelado matemático del consumo voluntario en rumiantes. 2. Principios y método para estimar el consumo potencial de materia seca de los pastos y forrajes tropicales. Rev. Cubana Ciencia Agrícola, 24, 51.

Sales, J. S., Iguma, L., Quintão, C. C., Gama, S., \& Freitas, C. (2015). Effects of a high-energy diet on oocyte quality and in vitro embryo production in Bos indicus and Bos taurus cows. Journal Dairy Science, 98, 3086-3099. https://doi.org/10.3168/jds.2014-8858

Sánchez-Castro, M. (2017). La hormona anti-mulleriana como un marcador endócrino asociado a la fertilidad postparto en Vacas Holstein La hormona antimulleriana como un marcador endócrino asociado a la fertilidad postparto en Vacas Holstein. La Sociedad Académica, 49, 50-56.

Santos, J. E. P., Bisinotto, R. S., \& Ribeiro, E. S. (2016). Mechanisms underlying reduced fertility in anovular dairy cows. Theriogenology, 86(1), 254-262. https://doi.org/10.1016/j.theriogenology.2016.04.038

Sartori, R., Gimenes, L. U., Monteiro, P. L. J., Melo, L. F., Baruselli, P. S., \& Bastos, M. R. (2016). Theriogenology Metabolic and endocrine differences between Bos taurus and Bos indicus females that impact the interaction of nutrition with reproduction. Theriogenology, 86(1), 32-40. https://doi.org/10.1016/j.theriogenology.2016.04.016

Schneider, C., Rasband, W., \& Eliceiri, K. (2012). NIH image to Image $\mathrm{J}$ : 25 years of image analysis. Nat Methods, 9 , 671-675. https://doi.org/10.1038/nmeth.2089 
Serrano-Pérez, B. (2020). Research in Veterinary Science Maternal nutrient restriction in early pregnancy increases the risk of late embryo loss despite no effects on peri-implantation interferonstimulated genes in suckler beef cattle. Research in Veterinary Science, 128(July 2019), 69-75. https://doi.org/10.1016/j.rvsc.2019.10.023

Shorten, P. R., Ledgard, A. M., Donnison, M., Pfeffer, P. L., Mcdonald, R. M., \& Berg, D. K. (2018). A mathematical model of the interaction between bovine blastocyst developmental stage and progesterone-stimulated uterine factors on differential embryonic development observed on Day 15 of gestation. 736-751. https://doi.org/10.3168/jds.2017-12845

Silva, V. L., Araújo, A. R., Henrique, H., Costa, A., Filho, M. A., Felipe, D., ... \& Xavier, P. B. (2016). Importância da nutrição enérgetica e proteica sobre a reprodução em ruminantes. Acta Kariri Pesq. e Des, 1(1), 38-47.

Snider, A. P., Mclean, D., \& Menino, J. A. R. (2019). E ff ects of feeding OmniGen-AF $®$ on superovulatory response in donor beef cows: I. Serum progesterone and cortisol, embryo recovery and quality. Animal Reproduction Science, 210(August), 106174. https://doi.org/10.1016/j.anireprosci.2019.106174

Sotelo, M., Núñez, J. C. S. S. F. Á. C. A. C., \& Arango, V. H. C. S. J. (2017). Sistemas sostenibles de producción ganadera en el contexto amazónico Sistemas silvopastoriles: ¿ una opción viable. CIAT. www.ciat.cgiar.org

Souza, A., Carvalho, P., Rozner, A., Vieira, L., Hackbart, K., \& Bender, R. (2015). Relationship between circulating anti-Müllerian hormone (AMH) and superovulatory response of high-producing dairy cow. Journal of Dairy Science, 98, 169-178. https://doi.org/10.3168/jds.2014-8182

Staal, A., Fetzer, I., Wang-erlandsson, L., Bosmans, J. H. C., Dekker, S. C., ..., \& Tuinenburg, O. A. (2020). Hysteresis of tropical forests in the 21st century. Nature Communications, 1-8. https://doi.org/10.5194/egusphere-egu2020-7217

Stephenson, J., Heslehurst, N., Hall, J., Schoenaker, D. A., Hutchinson, J., Cade, J. E., ... \& Mishra, G. D. (2018). Before the beginning: nutrition and lifestyle in the preconception period and its importance for future health. The Lancet, 391(10132), 1830-1841. https://doi.org/10.1016/S0140-6736(18)30311-8

Stokes, R. S., Ralph, A. R., Mickna, A. J., Chapple, W. P., Schroeder, A. R., Ireland, F. A., \& Shike, D. W. (2017). Effect of an injectable trace mineral at the initiation of a 14 day CIDR protocol on heifer performance and reproduction 1. https://doi.org/10.2527/tas2017.0050
Stringfellow, D., \& Seidel, S. (1998). Recommendations for the sanitary handling of in-vivo-derived embryos In: Strigfellow DA and SM Seidel (Eds) Manual of International Embryo Transfer Society. 3rd. Edition Savol IL IETS, 79-84.

Suárez, L. R., Tatiana, Y., Josa, P., Judith, E., Samboni, A., Dayana, K., Cifuentes, L., Humprey, E., Bautista, D., Carlos, J., \& Salazar, S. (2018). Soil macrofauna under different land uses in the Colombian Amazon. Pesq. Agropec. Bras., Brasília, 53(12), 1383-1391. https://doi.org/10.1590/s0100204x2018001200011

Summers, A. F., Rosasco, S. L., \& Scholljegerdes, E. J. (2018). Influence of management decisions during heifer development on enhancing reproductive success and cow longevity. Journal of Animal Science, 21, 1-25.

Tahuk, P. K., Budhi, S. P. S., Panjono and Baliarti, E. (2018). Nitrogen balance, microbial protein synthesis and blood metabolites in fattening of male Bali cattle fed ration with different protein levels in smallholder farms. Journal of the Indonesian Tropical Animal Agriculture, 6278(60), 43-53. https://doi.org/10.14710/jitaa.43.1.43-53

Torres Osorio, V., Urrego, R., \& Herrera, J. J. E. Z. A. L. (2019). Estrés oxidativo y el uso de antioxidantes en la producción in vitro de embriones mamíferos. Revisión. Revista Mexicana De Ciencias Pecuarias, 2 , https://doi.org/10.22319/rmcp.v10i2.4652

Yun-Wei, P., Xiao-Long, J., Shan-Jiang, Z., Zi-Qiang, H., \& Hua-Bin, Z. H. U. (2018). Beneficial role of melatonin in protecting mammalian gametes and embryos from oxidative damage. Journal of Integrative Agriculture, 17(10), 2320-2335. https://doi.org/10.1016/S2095-3119(18)61942-2

Zullo, G., De Canditiis, C., Pero, M. E., Albero, G., Salzano, A., Neglia, G., Campanile, G., \& Gasparrini, B. (2016). Crocetin improves the quality of in vitro-produced bovine embryos: Implications for blastocyst development, cryotolerance and apoptosis. Theriogenology, 86(8), 1879-1885. https://doi.org/10.1016/j.theriogenology.2016.06.011 